The Antiquaries fournal, 100, 2020, pp 190-212 (C) The Society of Antiquaries of London, 2019. This is an Open Access article, distributed under the terms of the Creative Commons Attribution licence (http://creativecommons.org/ licenses/by/4.0/), which permits unrestricted re-use, distribution, and reproduction in any medium, provided the original work is properly cited.

doi:I0.I0I7/Soo035815I9000015. First published online I6 September 2019

\title{
'BY THE IMPRESSION OF MY SEAL'. MEDIEVAL IDENTITY AND BUREAUCRACY: A CASE STUDY
}

\author{
Philippa M Hoskin, FSA and Elizabeth A New, FSA
}

Philippa M Hoskin, FSA, Professor of Medieval Studies, School of History \& Heritage, College of Arts, University of Lincoln, Brayford Pool, Lincoln, Lincolnshire LN6 7TS, UK. Email: phoskin@lincoln.ac.uk

Dr Elizabeth A New, Senior Lecturer in Medieval History, Department of History \& Welsh History, Aberystwyth University, Aberystwyth, Ceredigion SY23 3DY, UK. Email: ean@aber.ac.uk

This paper presents the results of a case study of wax seals dated between 1225 and 1250 from St Ethelbert's Hospital, Hereford. When medieval matrices were impressed into soft wax, handprints were often left on the reverse of the seal. The use of modern forensic techniques to capture and compare these prints provides evidence about the process of sealing and its relationship to the individual matrix owner. Seals with the same print on the reverse could be impressed with different matrices, and impressions of the same matrix have different prints on the reverse. The impressing of the matrix was not, then, as has been claimed, the responsibility of the matrix owner as the only way to impress their identity into the wax. This evidence allows a reappraisal of administrative developments in sealing, and the separation of the process of sealing from both the performance of livery of seisin and the seal owner.

\section{INTRODUCTION}

The study of seals and sealing practices is the study of representation and identity, of ideas and semiotics, and of administrative and legal developments. Seals can also on occasion provide unique evidence about an individual: the physical record of a person at a particular time and in a particular place, through the impression of hand and fingerprints in wax. ${ }^{\mathrm{I}}$ This article utilises such prints, in combination with the impression of seal matrices and written documents relating to St Ethelbert's Hospital in Hereford, to consider in detail the process of authentication. Through this it looks at the development of bureaucracy, and the ideas and reality of the presence, both immediate and, through the preservation of a sealed instrument, across time, of individuals involved in formalised exchanges in the Middle Ages. The following discussion also contributes to the debates - contemporary, medieval and modern - about the nature of the relationship between the seal matrix

I. Hand and fingerprints are also found on tiles and pottery, but these are often difficult to date with absolute precision and usually cannot be associated with a particular site of manufacture with any certainty. In contrast, the wax attached to documents can be dated (even without a dating clause, internal evidence can often narrow the point of production down to twenty to thirty years), and we have the precise context of its production. 
and its owner, and to what extent the mediation of the physical act of sealing through a third party was acceptable.

\section{SEALING PRACTICES: AN OVERVIEW}

The practice and evidence of sealing was not only a central part of the validation of documents, but also a vital component of the donor's consent to that grant expressed in tangible form through parchment and wax. Who was involved in the physical act of sealing is an important issue in understanding shifts in administrative practice and individual and institutional perception of the legal status of the document, as well as being part of a broader medieval academic debate around ideas of veracity, representation and identity.

For example, Michael Clanchy, in his seminal study of the shift from proof through oral testimony and symbolic exchanges featuring the transfer of a physical object before witnesses, to the adoption of the written record of such an exchange as proof in its own right, suggests that 'fixed to a charter, the seal became a relic which could be seen and touched, in order to obtain from it that authentic knowledge of a donor's wishes which no writing could adequately convey'. ${ }^{2}$

Brigitte Bedos-Rezak's pioneering work on seals and sealing practices also highlights the centrality of the matrix and impression as expressions of the owner's will, describing seals as 'active agents' and 'active expressions of their users', with 'power of becoming (the impressions) as well as simply of being (the intaglio matrices)' ${ }^{3}$ Furthermore, BedosRezak, Michael Pastoureau and others have noted the apparent importance, at least during the first couple of centuries of medieval Western European documentary sealing, of the physical contact between the sealer and both the matrix and the wax into which an impression is made. ${ }^{4}$ These are all debates to which this paper can contribute fresh evidence.

The sealing of documents as an integral part of the process of authenticating an exchange or agreement (that is, attaching to a document the impression of a seal matrix which was designed to remain, intact, with the written instrument) has very ancient origins, but there was a marked upsurge in this practice in north-western Europe in the eleventh century. ${ }^{5}$ In medieval Britain, the seal of validation became part of the administrative and legal process in the reign of Edward the Confessor, and by the early twelfth century the secular and ecclesiastical elites, along with a number of religious institutions, were sealing on a regular basis. ${ }^{6}$ During the twelfth and early thirteenth centuries the practice of documentary sealing spread rapidly, both socially and geographically, and by the later thirteenth century there were legal expectations for the sealing of exchanges of free land and property and the granting of substantive rights, and a general enthusiasm for sealing all manner of exchanges and agreements. ${ }^{7}$

2. Clanchy 2013, 317.

3. Bedos-Rezak 2010, 28.

4. Ibid, I5I, 200-I.

5. Ibid, chs 6-7.

6. Harvey and McGuinness I996, 5-6, 43, 63-4.

7. Ibid, 79. For a recent discussion of the spread of sealing, see McEwan 2015, 319-20. In addition to sealing in a documentary context, seals of closure were used for documents and a very wide range of items; see, for example, Brand 2015, III-I2. 
The act of sealing - the pressing of a seal matrix into a soft material to create an impression - elicited interest from medieval theologians and philosophers as well as lawyers and bureaucrats, especially when the material was wax. ${ }^{8}$ Before the advent of printing, the potential of a seal matrix, engraved with image and text, to produce multiple impressions that were identical but also unique items in their own right also raised questions about authenticity and replication of authority, ${ }^{9}$ and in pre-scholastic theology the impressing of a matrix into a plastic material was used in discussions of the act of Creation, the matrix of the divine being said to be imprinted into the malleable soul of man. ${ }^{\text {IO }}$

Despite a considerable amount of writing about, or using, the metaphor of sealing from a theological and philosophical perspective, and injunctions about the use of seals in legal and administrative contexts, there are surprisingly few descriptions of the actual physical act of sealing. In the royal chancery, several offices developed in the twelfth and thirteenth centuries that provide some information about the process in a busy administrative environment, and there are occasional references to the act of documentary sealing in legal records. ${ }^{\text {II }}$ Much of our information comes, however, from the physical material, which can be difficult to interpret, or which can seem to call into question general assumptions. By the later thirteenth century the physical practice of sealing seems to have shifted into the realm of an administrative process in many ways, although it is possible that - at least in an English context - there was still an expectation that the sigillant would directly participate in some way, even if only by touching the matrix or withdrawing it from the wax after it had been impressed by an administrator. ${ }^{\mathrm{I2}} \mathrm{A}$ survey of medieval documents at Hereford Cathedral as part of this project has revealed that this process is, however, rather more complex and unpredictable than perhaps has been appreciated. A focus on the back of the wax of pendent seals also demonstrates that a more nuanced approach must be taken when discussing the act of sealing. For example, the idea that the wax was pushed into the matrix and the back then shaped while the matrix was in place is not supported by the evidence, where on many occasions it is clear that the wax cakes must have rested in the palm

8. For example, Bedos-Rezak 2006, 46-64.

9. Bedos-Rezak 20I2, 216-36.

I0. For a discussion of this and wider theological issues, see Bedos-Rezak 2010, especially chs 5 and 6, and Bedos-Rezak 2006.

II. The offices of spigurnal and chafewax developed in the royal chancery during the thirteenth century: New 2010, 40. For good examples of references to sealing in legal contexts, see Brand 2015. It should, however, be noted that sealing clauses are often formulaic, and one needs to exercise caution with the phrase 'my seal' and take note of the context in which it is used; see below for a further discussion about this point.

I2. In a I294 attaint of an assize of novel disseisin, a young woman testified that she had been coerced into validating an agreement, and that when she had told them she did not know how sealing a document was done, a clerk prepared the wax and impressed the matrix, and she had to withdraw the matrix from the wax before witnesses: Brand 2015, II4. Exactly when and to what extent a shift from full participation of the sigillant in the physical act of sealing occurred, if indeed the imperative for the seal owner to impress their matrix physically ever existed or completely disappeared, are among the issues investigated by the AHRC project, 'Imprint: A forensic and historical investigation of fingerprints on medieval seals'; AHRC Project AH/MoI08I3/I <http://gtr.rcuk.ac.uk/projects?ref=AH\%2FMoI0813\%2FI > (accessed I4 Feb 20I9). The project, which ran from January 2016 to December 20I8, was headed by Professor Philippa Hoskin at the University of Lincoln and Dr Elizabeth New at Aberystwyth University, with research fellows Dr Hollie Morgan and Dr Fergus Oakes. 
with the matrix impressed from above. ${ }^{13}$ There are also a number of examples where the impression of the principal matrix is overlaid with handprints in instances when there is the impression of a subsidiary matrix on the back of the wax, again questioning the assumption (and indeed logical conclusion) that the wax remained placed in the main matrix while the subsidiary one was impressed. ${ }^{\mathrm{I}}$ An analysis of the findings at Hereford helps us, as we will now show, to better understand both administrative processes and how seals and sealing, with the attendant questions of representation, identity, authentication and exercise of authority, actually worked in practice rather than just in theory.

\section{THE PHYSICAL PROCESS OF SEALING: ANALYSING THE EVIDENCE OF HAND- AND FINGERPRINTS}

In order to investigate whether it is possible to identify hand- and fingerprints from medieval seals, and to see if the results provide any useful information, a sample of sealed documents from Hereford Cathedral Archives (HCA) was analysed by a forensic identity science expert in conjunction with the authors. ${ }^{15}$ The documents chosen were from the late twelfth to mid-fourteenth centuries, a period of considerable change in administrative and sealing practices. ${ }^{16}$ Out of 220 sealed documents examined for the study, 207 had visible hand- or fingerprints on the wax into which a seal matrix had also been impressed, of which 176 were viable (that is, some form of analysis was possible) and fifty-eight had prints classified as 'good'. ${ }^{77}$ Fifty-two of these good prints were from palms (most showing a clear distal transverse crease - the crease running horizontally across the upper part of the palm indicating that the person holding the wax was cupping their hand), three from fingers, one probable finger and two which included prints both from the palm and fingers of the same

13. HCA 82 I has a clear palm print with no overlaid prints, for example. Hilary Jenkinson proposed that the wax was pressed into the matrix rather than the other way around, but provided no historical evidence to support this: Jenkinson 1968, I0. For a re-creation of impressing a seal by pushing wax into the matrix, see <https://www.youtube.com/watch?v=UsTNyhL4VYE $>$ (accessed I4 Feb 2019).

I4. HCA I59, for example.

15. The forensic analysis was carried out in 2013 by Luke McGarr of Forensic Focus Ltd. The authors are grateful to Mrs Rosalind Caird, the Cathedral Archivist at the time, and other staff at Hereford Cathedral Archives for their assistance. Further details of this project are provided below.

I6. Harvey and McGuinness I996, 77-9. Initial data from the Imprint project indicates that the number of visible prints varies between collections, for reasons that require further investigation. In addition, Imprint used a multi-spectral imager and employed automated as well as manual identification techniques (the pilot project relied on traditional photography and employed only manual identification).

17. For an explanation of the process of defining prints as 'good' in this context, see McGarr et al 2016, 7-9. Hand- and fingerprints do not change over the course of a lifetime (although, of course, they proportionally increase in size as a child grows to adulthood) and generally are very resilient to change through injury, which makes it possible to trace an individual over many years, but makes it impossible to sequence the prints in terms of how old someone is without further context. In general terms. the palm and fingerprints of men and women exhibit some slight differences, but it is difficult to be precise about this. For an introduction to fingerprints and the history of identity science, see Cole 2002. 
hand. ${ }^{18}$ The majority of prints were single deposits, with an individual identified only once in the sample, but there were individuals whose prints appear on more than one seal, one of whom handled the wax seals on no fewer than five separate documents. Although it is not always possible to tell if prints are male or female, it seems probable to the forensic expert that these are male prints, lacking the shape of a female palm. It is here that we turn to St Ethelbert's Hospital in Hereford.

The seals in this case study are attached to a number of land grants and confirmations of the second quarter of the thirteenth century, all in favour of one institution in the English city of Hereford. In the mid-I220s, Elias of Bristol, one of the canons of Hereford Cathedral, founded a hospital, dedicated to St Ethelbert, which is said in contemporary documents to have been both on the fief of William Marshall (presumably Stephen son of Hugh, from whom Elias purchased the land, held it of the earl) and 'next to the cemetery of St Ethelbert' that is adjacent to the cathedral. ${ }^{19}$ The detailed chronology of the hospital is uncertain, but there was a building on the site by the I230s when Master Reginald was described as custos there, with three confratres, or brothers. ${ }^{20}$ By 1252 documentation of the quarrel between the then bishop of Hereford, Peter de Aigueblanche, and St Ethelbert's included an accusation that they were not providing properly for the Ioo poor there, suggesting large numbers of people were seeking alms by that date, although presumably with so few brothers the suppliants were not living on the premises. ${ }^{2 \mathrm{I}}$ Elias, a former royal servant, had dedicated the hospital to the memory of King John as well as placing it under the authority of the Dean and Chapter, and he obtained a number of indulgences for it from bishops across England and Wales. ${ }^{22}$ Elias himself also made additional donations to the hospital from his property in and around Hereford, ${ }^{23}$ and the hospital of St Augustine's in Bristol - presumably Elias's home town - also made a grant to the new institution. ${ }^{24}$ The majority of the land the hospital received over the twenty-five years or so after Elias's foundation (thus, from the mid-I220s) was given in small amounts, however, by landholders in and around Hereford. The documents detailing these gifts and confirmations form a valuable collection, and provide an ideal sample for investigating questions relating to sealing and administrative practices. In particular, the short chronological range and geographically limited nature of the exchanges and parties involved lend themselves to a forensic study of the hand- and fingerprints visible on the wax seals.

\section{THE ST ETHELBERT HOSPITAL COLLECTION: A CASE STUDY OF SEALING PRACTICES}

The evidence of the prints on these seals allows us to investigate in particular two different types of cases: those of matching prints from the same individual on more than one wax, and of non-matches where impressions of an identical matrix are linked to several different

I8. The authors are grateful to Luke McGarr and Dr Karen Stow for analysing and interpreting the print data.

I9. HCA 2,00I, 898, 832, 86I, 929; Capes I908, 57-8, 6I-3; Whitehead I986, 4I5-25.

20. HCA 305, 2,012, 2,013, 935, 894.

2I. Whitehead 2000, 60I.

22. New 2015a, 67.

23. HCA 78I, 783, 980, 2,00I; Capes I908, 57-60.

24. HCA 998; Capes 1908, 56-7. 


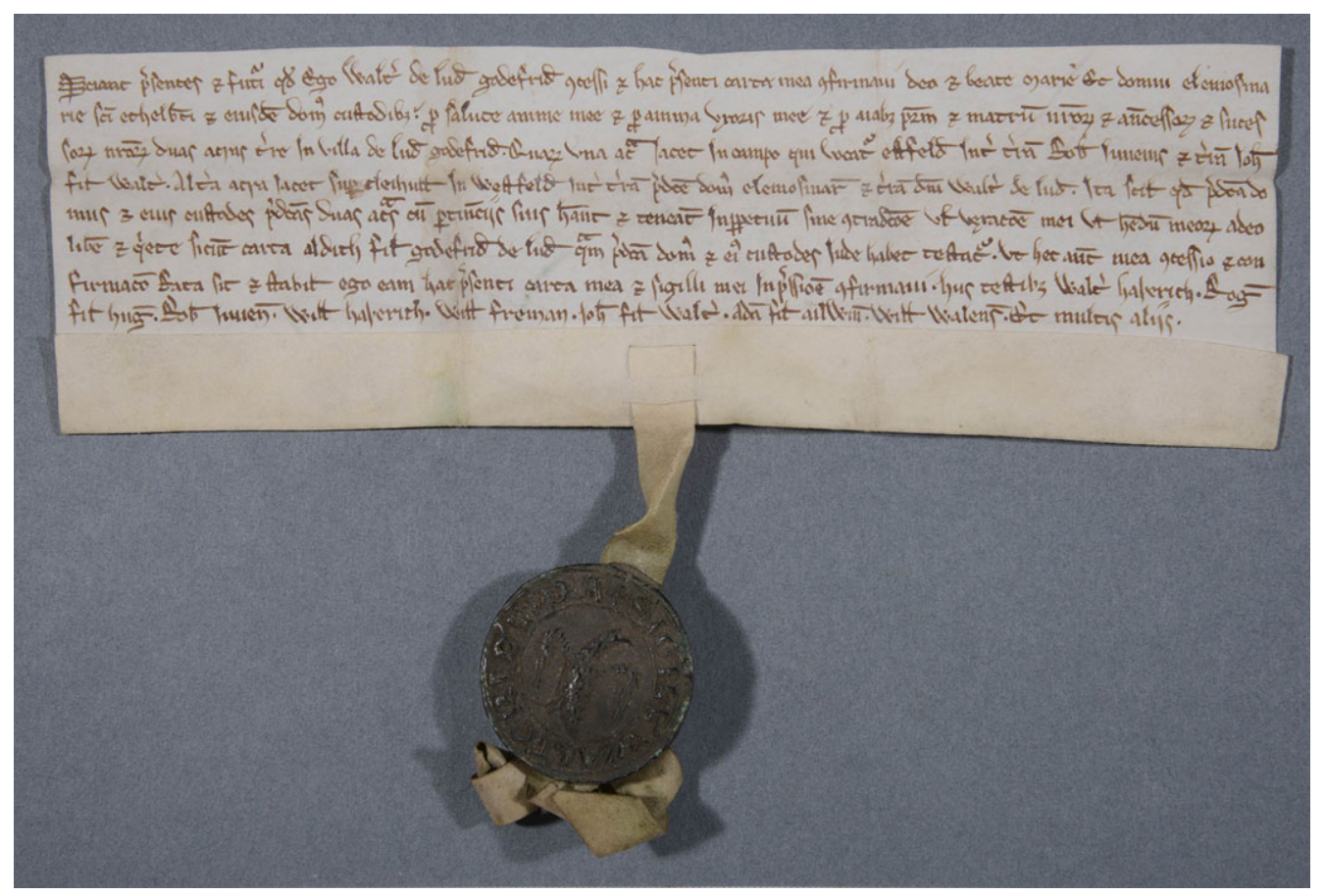

Fig Ia. Grant of Walter of Lyde Godfrey to the Hospital of St Ethelbert (HCA 82I). Photograph: the authors.

handprints, revealing the presence of different individuals handling different waxes. Together these tell a story about the development of sealing and administrative practice, and about the seal as an individual's identity.

The hospital deeds include five documents from this twenty-five year period of $c$ I22550 (fig ra-e), where an individual's same handprint appears on the reverse of all the wax seals attached, although they are issued in the names of five different grantors: Walter of Lyde Godfrey; John, son of Walter; Hugh, son of Ailmund; William Long; and Osbert, son of Suin. ${ }^{25}$

Why did this occur? Some possibilities about the administrative process can be ruled out immediately. The seals were not necessarily affixed by either the scribe or the drafter of the document. These two individuals and the document's sealer were usually three different people in ecclesiastical chanceries, ${ }^{26}$ but even setting this aside it is clear that the documents under investigation are not all in the same hand, nor is the diplomatic close enough to suggest a single drafter. Although the looped ascenders of the lowercase ds, the shape of the majuscule $\mathbf{S}$ at the start of the documents, the noticeably upright lowercase $\mathbf{f}$ and the shape of the general abbreviation mark make it possible that the same scribe wrote the grants by Osbert, son of Suin, and Hugh, son of Ailmund, there are distinct differences in the letter forms between these and the other three documents: the majuscule $\mathbf{M}$ forms a contrast, for example, between the document of Hugh, son of Ailmund, and that of 


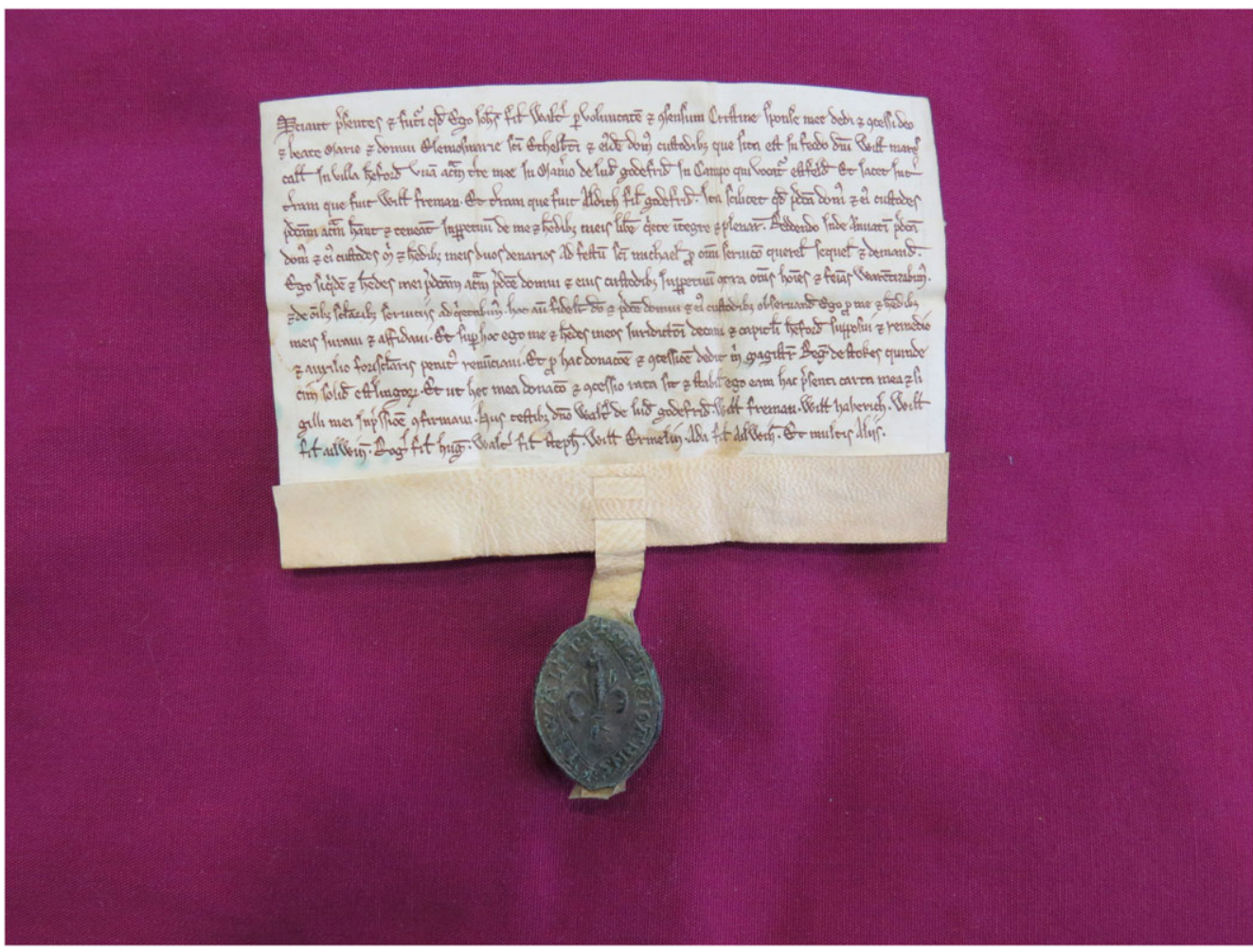

Fig Ib. Grant of John, son of Walter, to the Hospital of St Ethelbert (HCA 832). Photograph: the authors.

Walter of Lyde Godfrey. William Long's charter includes a lowercase letter 'd' without a looped ascender and with a distinct majuscule E. ${ }^{27}$ Neither are the documents' diplomatic identical. Generally, they are standard in the way one would expect of private grants at this date, all beginning Sciant presentes et futuri quod ego, making use of the first-person singular, and containing very similar, though not identical, corroboration clauses. Overall, they reflect the phrasing of the many grants to St Ethelbert's which survive for the second quarter of the thirteenth century. The description of the house varies, however. All the grants are made to the almonry, but only some of them elaborate their description of the hospital to make mention of its place on William Marshall's fief. This is not an addition that adds to

27. As far as it is possible to be certain with such brief notes, the thirteenth-century endorsements for these five documents seem to be in the hand of the scribe of the main text. Certainly, there is nothing significant about them that would suggest one hand for all five. A comparison of several documents by the most frequent grantor of these five, Walter of Lyde Godfrey, reveals that these are in a variety of hands (see HCA $8 \mathrm{I} 7,82 \mathrm{I}, 846$ ), so clearly it was not usual practice for one individual always to return to the same scribe. It seems most probable that the documents were drawn up by the recipient, as would be the practice in large ecclesiastical chanceries at this date, but using a range of scribes. The authors are grateful to Dr Tessa Webber for her comments on these documents. 


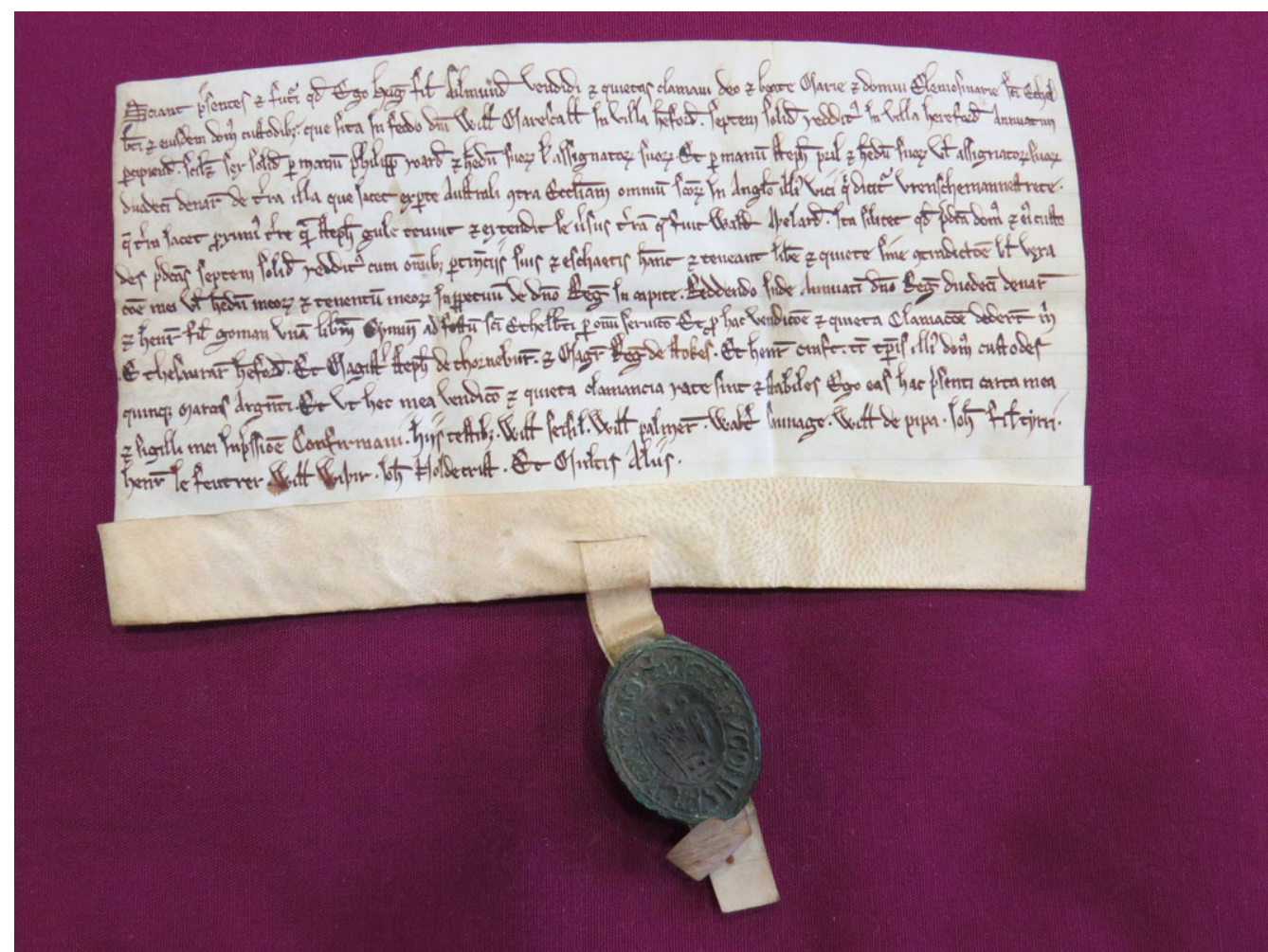

Fig Ic. Grant of Hugh, son of Ailmund, to the Hospital of St Ethelbert (HCA 86I). Photograph: the authors.

the particular charters under investigation, but instead seems to be a drafter's choice of qualifier. $^{28}$

There is also no reason to think that these grants were made on the same occasion. They do not all concern land in one area: two certainly refer to land in the Lyde area, north of Hereford, in the field called Eastfield, and are presumably therefore close to each other, ${ }^{29}$ but the remaining three parcels of land are in Clehonger to the west of the city, about ten miles from Lyde. Therefore, as a group of documents they are unlikely to be the result of a dispute settlement for the parcelling up and transference of large numbers of small parcels of land in one go, as perhaps part of a land exchange. ${ }^{30}$ Nor do their witness lists suggest that they were all issued on one occasion (as is usual for private deeds of the first half of the thirteenth century, none have a dating clause). It is true that some of these grantors act as witnesses to each other's grants within these five charters, but they do not do so consistently and no more than one of these five men witnesses any one of this group of charters. The remaining witnesses also differ. Men such as William de Pipe, Roger, son of Ythel,

28. Those that do contain this additional description are HCA 832, 86I and 929.

29. HCA 821,832 .

30. Such exchanges were not uncommon for institutions that often received gifts of small amounts of land and wished to consolidate it, particularly in the thirteenth century. See Golding I995, 285-6. 


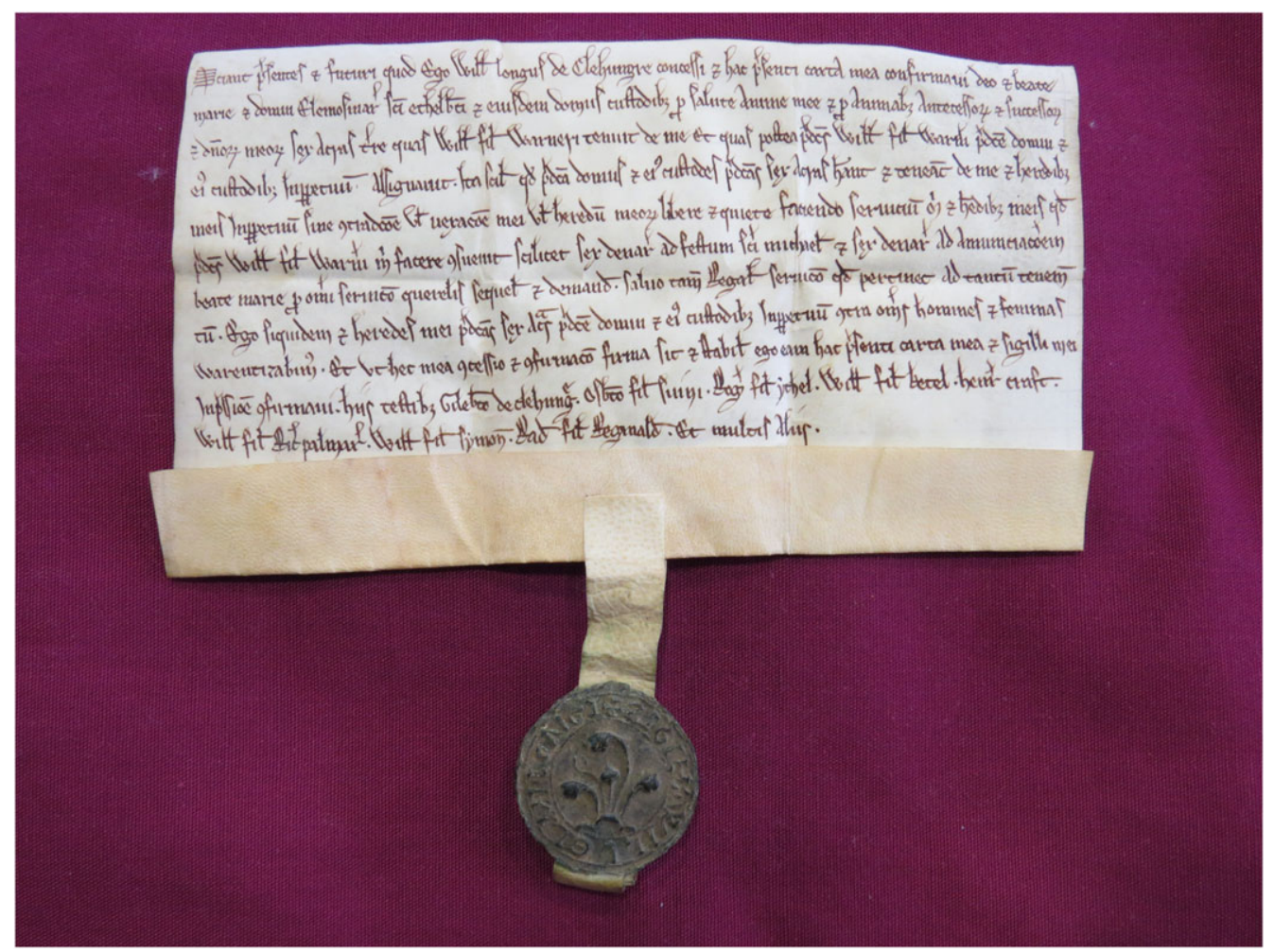

Fig Id. Grant of William Long to the Hospital of St Ethelbert (HCA 915). Photograph: the authors.

William Hatherich, William Freman and Henry Craft witness more than one of the documents, but never all five, ${ }^{3 \mathrm{I}}$ and some men, such as Roger, the parson of La More, appear only once. ${ }^{32}$ These repeated witnesses are also commonly found in a whole range of documents issued in favour of St Ethelbert's, both as witnesses and as grantors, their links being to the hospital as a whole.

Perhaps, then, the answer to the same individual's prints occurring on all the wax seals lies in the networks, property and dwelling places of the individual grantors. Who were the five people who made these grants? Of some of them we know very little indeed. John, son of Walter, whose charter grants land in Lyde Godfrey to the almshouse with the agreement of his wife Christina, is not otherwise found in the hospital's charters. ${ }^{33}$ Osbert, son of Suin, is found only in this grant and one or two witness lists and must have died not far past the mid-thirteenth century: his widow, Agnes, quitclaimed five acres of Clehonger land from her dowry to the hospital in the middle of the century. ${ }^{34}$

Others have left more of a trace in the records. Hugh, son of Ailmund, had long family connections within the Clehonger area. His father made a number of small grants of

3I. William de la Pipe (HCA 86I, 929), Roger, son of Ythel (HCA 915, 929), William Hatherich (HCA 821, 832), William Freman (HCA 821, 832) and Henry Craft (HCA 915, 929).

32. HCA 832.

33. Ibid.

34. HCA 915, 923. 


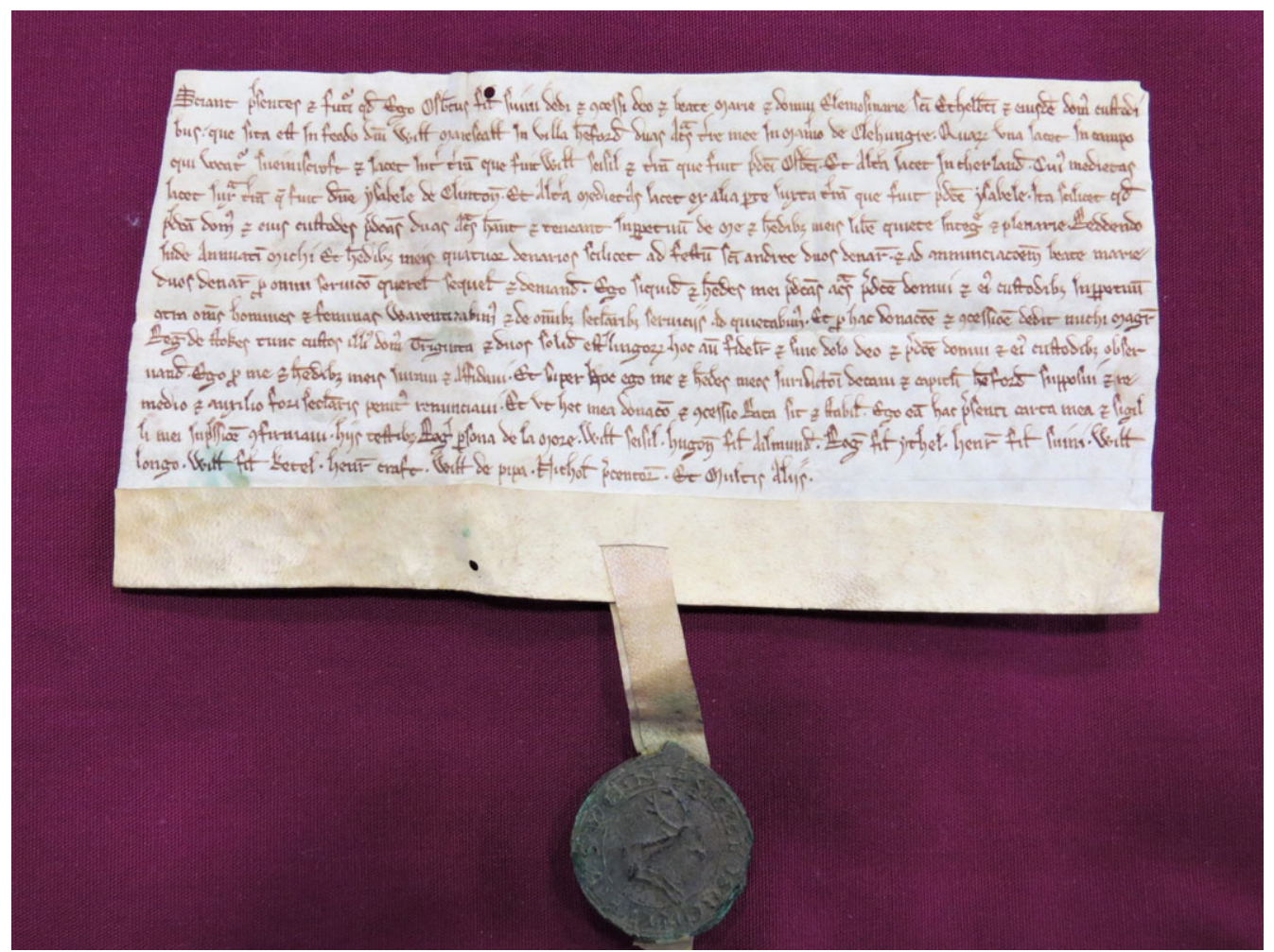

Fig Ie. Grant of Osbert, son of Suin, to the Hospital of St Ethelbert (HCA 929). Photograph: the authors.

Clehonger property to individuals and institutions, ${ }^{35}$ and his brothers, Ingeram and John, also witness charters and make their own grants of property in Clehonger. ${ }^{6}$ Hugh appears as witness to charters across the first half of the thirteenth century, from around Clehonger and in the city of Hereford, including grants to the cathedral. ${ }^{37} \mathrm{He}$ also had property in the city and familial connections with the cathedral. In summer 1228 he was recorded on the fine rolls as one of the cancelled amercements of Hereford; he had owed one mark, and his pledge had been Henry Craft, one of the masters of the almshouse, with whom he had witnessed other people's grants to the almshouse..$^{38}$ In addition, several members of his family appear in the Hereford obit book. Annora, described as the wife of Ailmund the miller, was remembered on I July for her gift of six pence, and Alan the miller, Hugh's grandfather, was also recorded, under 24 August, for his gift of land worth six pence. ${ }^{39}$

35. HCA I,235, 550, 933, 930, 9II, 907, 909.

36. HCA 959, 972, I,205, I,206, I,207.

37. HCA 838, 863, 867, 929, 926, 927, 928, 960, I,I03, I,279, I,280, I,698; Barrow 2002 , I34.

38. Dryburgh and Hartland 2008, 2I6. For the two men witnessing together, see HCA 640, 39I, 505, 938, 838, 863, 867 and 869. For Henry Craft as master of the hospital, see HCA 804.

39. HCA I,275 for his widow's grant: Hugh's land in Hereford is also mentioned in the Hereford obit book, locating the land granted by Margaret the moneyer, whose land was between that of Hugh and that of Nicholas the cantor: Barrow 2002, I58. For Ailmund and Alan the miller, see Barrow 2002, I28, I38. 
The document of William Long of Clehonger is among this group of five charters and confirmed a grant of six acres of land, which William, son of Warner, had held from William Long but had granted to the house of St Ethelbert's. ${ }^{\circ}{ }^{\circ}$ William had land about six miles west of Clehonger, and was clearly active in the area in the I230s making grants and witnessing charters. ${ }^{4 \mathrm{I}}$

The final grantor in this group was Walter of Lyde Godfrey, sometimes called Walter, son of Nicholas. Like John, son of Walter, his landholdings were in Lyde Godfrey (now known as Upper Lyde), to the north side of Hereford where Clehonger is to the west, and he too witnesses many charters in favour of St Ethelbert's in the period I225-50. ${ }^{42}$

All five of these grantors, then, were men whose concerns were local, not national. They witnessed grants for each other and for other small local landowners, mainly in their own areas of influence, regularly appearing as both donors and witnesses in the surviving thirteenth-century grants to St Ethelbert's Hospital, and having their grants witnessed by these men in turn. All of them must have been relatively well-to-do as they were landowners, albeit small landowners, and, as they were sought as witnesses to documents, would have been people of good legal standing. ${ }^{43}$ They did not, as far as we can tell, share a common lord. The Devreux family were lords of Clehonger at this date, while Lyde Godfrey was held of the honour of Weobley from the de Lacy's by Richard Feythou. ${ }^{44}$ Their relationship with the cathedral itself was limited: none of them was obviously wealthy enough to make grants to that body that would have allowed them in a place in the Hereford obits, and they had little involvement with grants made directly to the Dean and Chapter.

If no obvious connections can be made between the drafter, scribe or principal party involved in the five documents under investigation, but one person handled the wax in each case, do the sealing practices and the physical imprinting of the matrix reveal any obvious association? As part of such an investigation it is also important to see if there are any discernible similarities or differences in the mechanical process of sealing (as far as can be determined from the extant material) in the instances where documents were validated by the same sigillant. In essence, without the print analysis, is there any way in which we can associate different sealers - the person who actually held the wax and impressed the matrix (assuming that they were one and the same) - with these five extant pendent seals?

Nothing that we can identify about the process of sealing these documents makes them a distinctive group. Indeed, in terms of documentary evidence there is, as would be expected in the first half of the thirteenth century, no indication that anyone other than the sigillant was involved in the actual act of sealing, and in each of the five cases the sealing clause is standard for the period and concludes sigilli mei impressione confirmaui. ${ }^{45}$ All five documents with handprints from the same person on the wax are also sealed using a very similar shade of green wax and on a parchment 'tag', a strip of parchment threaded through the turn-up

40. HCA 9I5. The grant of this property to William, son of Warner, by William Long is HCA 9II. 4I. HCA 908, 920, 922, 923, 924, 926, 927, 929, 932, 935, 939, 94I, 944, I, 205-I, 208, I, 2 I4, I, 236. $\mathrm{He}$ also acted as pledge to the document.

42. HCA 844, 848, 835, 837, 82 I, 834, 839, 837, 8II , 82 I, 846, 8I 7, 808, 2, 002, 830, 832, 83I, 826, $836,833,819,850,812,844,810,806,823,824,820,818,805,855,856,826,816,845,814,809$, 815 .

43. Julia Barrow notes that the relationships between the cathedral and the citizens of Hereford were with a small number of well-to-do citizens who had property interests: Barrow I999, I4-I5. The five grantors discussed here represent much the same sort of person.

44. Holden 2008, I00; Galbraith and Tait I950, 98.

45. See below for the significance of the reference to the impression rather than affixing of the seal. On thirteenth-century sealing, see Harvey I99I, especially II2-I3. 
at the foot of the document, a common way of attaching a seal in medieval England and Wales and again, as was usual, they were on 'clean' rather than reused parchment. ${ }^{46}$ In three instances (HCA 832, 915, 929; figs Ib, Id, Ie) the wax has been attached quite low down on the tag in relation to its total length, but on the other two (HCA 82I, 86I; figs Ia, Ic) the wax has carefully been placed near the centre of the tag. ${ }^{47}$ In all five cases there is, however, room for the seal impression to be folded up within the document, suggesting a familiarity with the preparation and storage of sealed instruments on the part of someone involved in process..$^{4}$ As with the form of attachment, the colour of the wax does not appear to be of note since wax of an almost identical shade was used quite frequently on documents relating to Hereford Cathedral and to St Ethelbert's Hospital in the same period. ${ }^{49}$ Moreover, from information currently available it seems as though green wax was a popular choice for sealing across England and Wales, especially in the thirteenth century, ${ }^{50}$ perhaps because the pigment (verdigris) was easy to procure, or because it was noticed that uncoloured wax deteriorated more quickly than coloured wax. ${ }^{5 \mathrm{I}}$ In terms of the actual disk of wax into which the matrix was impressed, in all five instances the upper cake is thinner than the lower, but again this is extremely common and only in one instance (HCA 86I) is the top cake thin enough to have started to come away as a result of

46. It has been suggested that the way the parchment strips of the tag were folded or knotted prior to the application of the wax cakes may provide insights into clerical and sealing practices: Jacquet 20IO. It is interesting to speculate whether similar studies, combined with palaeographical investigations and print analysis on the wax, could provide a more nuanced understanding of the process of producing sealed instruments. In the sample of seals recorded by the AHRC-funded 'Seals in Medieval Wales' project (AH/Goro994/I), 2,637 of 3,I68 seal impressions are attached by tags. Tongues seem to have been used quite widely in the first century of sealing for documentary validation and may have fallen out of favour for important documents when it was realised that they were vulnerable to tearing and the seal impression being lost; in I294, for example, a bond was challenged because the tongue with the seal impression had become detached, allegedly in the crowded courtroom: Brand 2015, III-I9. Their subsequent increase in use in the late medieval period might have been a result of increased documentary production and the need for speed: Harvey and McGuinness I996, 20. The seal of Walter of Lyde Godfrey was impressed into wax attached to a tag made from another document on HCA 846, but on clean parchment on HCA $82 \mathrm{I}$, suggesting that the person preparing the document for sealing simply used what was available at the time.

47. On HCA 832, only a couple of millimetres of the parchment tags emerge from the bottom of the wax, although this may be the result of deliberate or accidental damage.

48. A broken or detached seal could cause the validity of the document. For example, in 1292 a case was brought before the Common Bench in which a bond supposedly issued by the prior of Castle Acre was challenged on the grounds that the seal impression was broken and 'decrepit': Brand 20I5, II3.

49. See, for example, HCA 948, a grant of Robert le Rus to the Hospital of St Ethelbert. It is, of course, possible that an analysis of the exact composition of the sealing wax (for example, the proportion of verdigris used or presence or absence of a resin) could reveal subtle differences.

50. Approximately 40 per cent of the seal impressions recorded from twelfth- and thirteenth-century London are in green wax: for example, McEwan $2016 \mathrm{a}$.

5I. Modern scientific studies have confirmed that green sealing wax was indeed coloured using verdigris (copper acetate), Woods I994, 203-I4, among others. The deterioration of uncoloured wax in relation to that with a pigment is a matter of considerable debate among contemporary conservators and archivists: see, for example, $<$ http://www.sigillvm.net/fileadmin/media/folderI/ Coloured_seal_survive_better_02.05.20I6.pdf > (accessed I4 Feb 20I9). 
movement from the tags, as the document and pendant seal has been handled over the centuries..$^{52}$

While it is impossible to reconstruct fully the actual impressing of the matrix into the soft wax, and adult palm prints do not change with age so no chronology of the seals is possible, some clues may be gleaned from the extant items. All five seals have name legends that correspond to the principal party in the document, and all have a small cross to indicate the start of the legend, the most common format for the inscription on seals of this date. ${ }^{53}$ Impressions of matrices of this type are, typically, orientated with the central motif and/or the legend cross reasonably central to the attachment (the cross in the legend band typically being at 12 o'clock in relation to the motif). Of the five seals under consideration all are reasonably well positioned. In three instances the matrix has either not been aligned absolutely centrally to the tag or with the cross orientated slightly off-centre, ${ }^{54}$ but this is not in itself a clear indicator that someone unfamiliar with the process of documentary sealing was holding a particular matrix. Affixing cakes of wax to a tag, moulding them to form a smooth disk ready to take an impression, and impressing a matrix in the correct position and removing it cleanly is rather more challenging than it might sound, and there are numerous examples of sealings, including those of officials or institutions, where there are some 'faults' in the impression. ${ }^{55}$ Without the handprint evidence, the discrepancy in the accuracy of attaching the wax or impressing the matrix might suggest to the researcher that different people may have been involved in the sealing process.

One final point to consider is whether anything about the matrices used could suggest a point of commonality. This is of course extremely difficult to determine in the absence of the actual objects, but the surviving impressions provide some clues. One of the fives matrices in the set, that of Hugh son of Ailmund, was of the 'ancient gem' type, with a carved seal-stone set into a metal mount (fig 2a)..$^{56}$ The central motif depicts three figures with an object at their feet, an image which, it might be suggested, could have been interpreted by a medieval viewer as a Christian motif, perhaps the shepherds adoring the Christ-child. ${ }^{57}$ Setting seal-stones, especially genuinely ancient items, into a metal mount required a

52. Although a clear crack can be seen between the upper and lower cakes of wax on HCA 86I the top cake does not appear to be loose at the time of writing, and Hereford Cathedral Archives have a programme of monitoring and repackaging material to safeguard this for the future.

53. Harvey I99I, I20; McEwan 2016b, 24.

54. HCA 832 and 86I have the cakes of wax and subsequent impression aligned very slightly offcentre on the tag; on HCA 929 the wax is centred on the tag but the matrix has been impressed with the cross in the legend band at approximately 2 o'clock in relation to the centre of the tag.

55. An example of a 'faulty' seal is the fragmentary impression of the London Common Seal attached to a document dated 1285 in which the upper wax disc appears to have moved slightly when the matrix was applied, London Metropolitan Archives CLA//007/EM/02/F/053, reproduced in New 20I5b, fig Ic. For the complexity of the process of preparing wax and impressing a matrix, see the note of experimentation by the Imprint project team http://imprintproject.blogs. lincoln.ac.uk/20I6/IO/3I/on-making-wax-seals/ (accessed I4 Feb 20I9).

56. HCA 86I. The legend names him as Hugh, son of Eilmund (SIGILL' HVGONIS FILII EILMVND'). The term 'ancient gem' is generally used by sigillographers for stones engraved intaglio and in reverse (that is, clearly designed to be used as a seal) both from the ancient world and those which were manufactured in the Middle Ages in the manner of Classical seal-stones. The authors are grateful to Martin Henig for his opinion that the seal-stone set in Hugh's matrix would, from the impression, appear to be first century BC and that the image may originally have been intended to represent a sacrifice of some kind.

57. The authors are grateful to one of the anonymous reviewers for the suggestion that the scene could have been interpreted as the shepherds at the Nativity. 


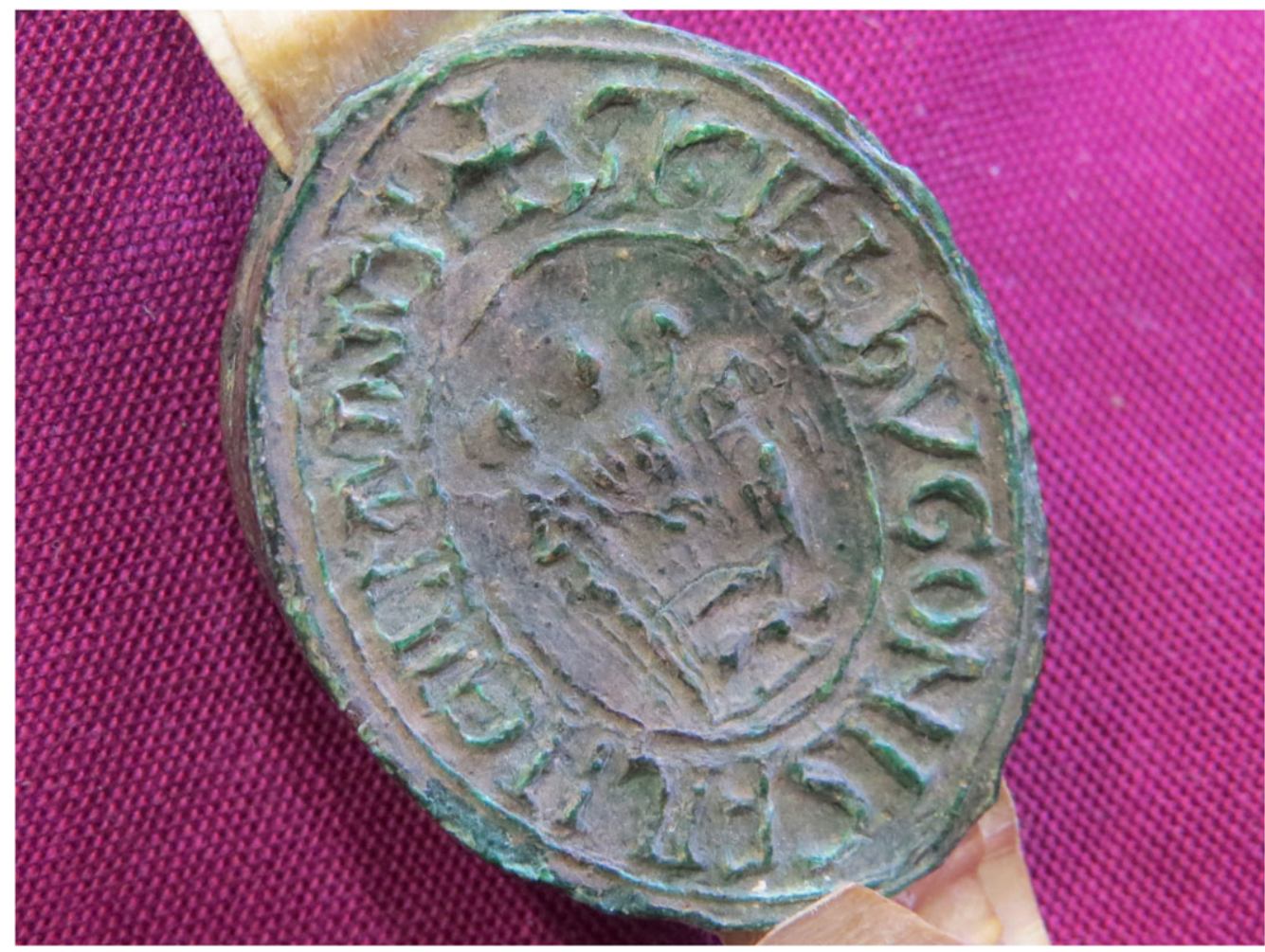

Fig 2a. Impression of the seal of Hugh, son of Ailmund (HCA 86I). Photograph: the authors.

skilled artisan, and such matrices are usually considered an indicator of some degree of, or aspiration to, wealth or status..$^{8}$ This fits with what else we know about Hugh and his family, as discussed above, although it is possible that the matrix was also an heirloom of some sort, for the impression suggests that the legend may have been re-engraved.

The four other matrices in this set all appear from the extant impressions to have been made from a single element, almost certainly metal at this date. ${ }^{59}$ Three are round and one a pointed oval, and all have the standard format of a central motif surrounded by a name legend. Each has a different image, standard in the sense that the generic type of motif is found on numerous other seals of this period, but in three cases with variants that make them stand out and which suggest that seal owners in thirteenth-century Hereford had a choice of supplier when choosing their matrix. The seal of Walter of Lyde Godfrey depicts a bird with wings outstretched and its head turned back (fig 2 b), a reasonably popular motif in this part of Britain at this time; ${ }^{60}$ the impression suggests a matrix engraved by someone familiar with the process in terms of the placing of the image within the field and spacing of letters in the legend band. At first glance, the seal of John son of Walter is also quite typical

58. Henig $2007,25-34$.

59. Metal became by far the most common material for matrices from the third quarter of the twelfth century onwards; see Heslop I986.

60. HCA 82I. McEwan 2016b, 2I-3, fig I.22, table I.4. 


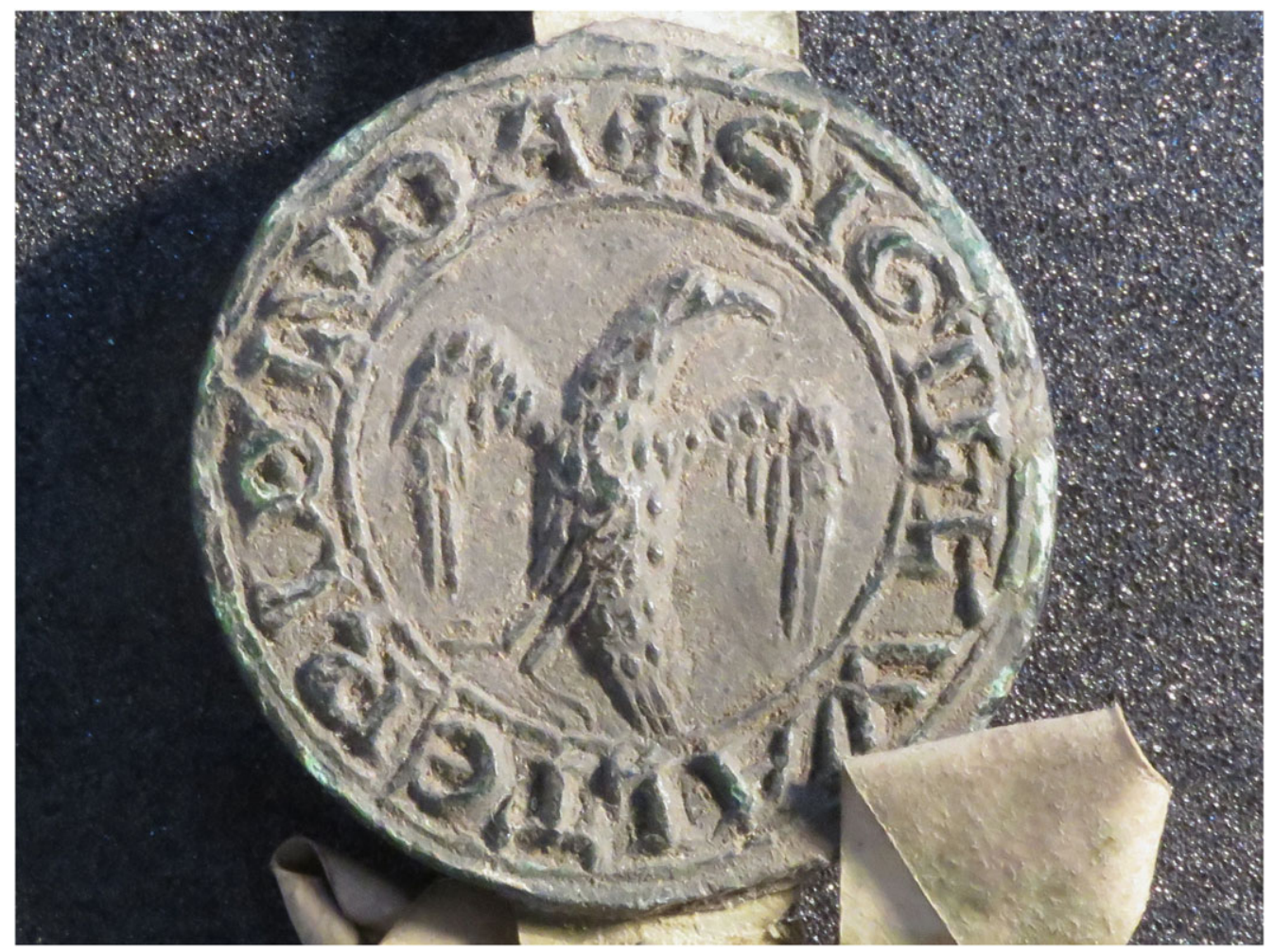

Fig 2b. Impression of the seal of Walter of Lyde Godfrey (HCA 82I). Photograph: the authors.

for its time and place, with the motif of a stylised lily (fig 2c) ${ }^{6 \mathrm{I}}$ Very unusually, however, emerging from the central floret of the lily is a small trefoil. This appears to be a quite deliberate feature which, from the impression, seems to have been carefully engraved, and it is tempting to speculate whether John requested something to distinguish his seal from that of numerous others with a similar motif in a manner similar to the way in which marks of difference were beginning to be incorporated into armorial bearings in this period. ${ }^{62}$ The seal of William Long has as a central motif stylised foliage, once again a reasonably common image but executed in an unusual manner (fig $2 \mathrm{~d}$ ). ${ }^{63}$ Moreover, the fine engraving indicated by the impression and the rather 'fleshy' trefoil terminals of the foliage are very similar to those found on a number of other seals impressed on St Ethelbert and Hereford Cathedral documents of this period, hinting at an accomplished seal-maker operating within the city. ${ }^{64}$ Finally, the seal of Osbert, son of Swein, has as a motif the head

6I. HCA 832. McEwan 20I6b, I8, 2I, fig I.22, table I.4.

62. This further supports the contention that we should not privilege 'correct' armorial bearings over other motifs in this period, since it is becoming increasingly clear that the semiotics of representation are far more complex and reached further across society than previously perhaps has been fully appreciated: see, for example, New 2015c.

63. HCA 915.

64. Other examples of the fleshy trefoils include the impression of the matrix with a beautifullyrendered and complex stylised lily that belonged to Ailmund, son of Alan the miller (father of Hugh, son of Ailmund), attached to HCA 9 II among others. 


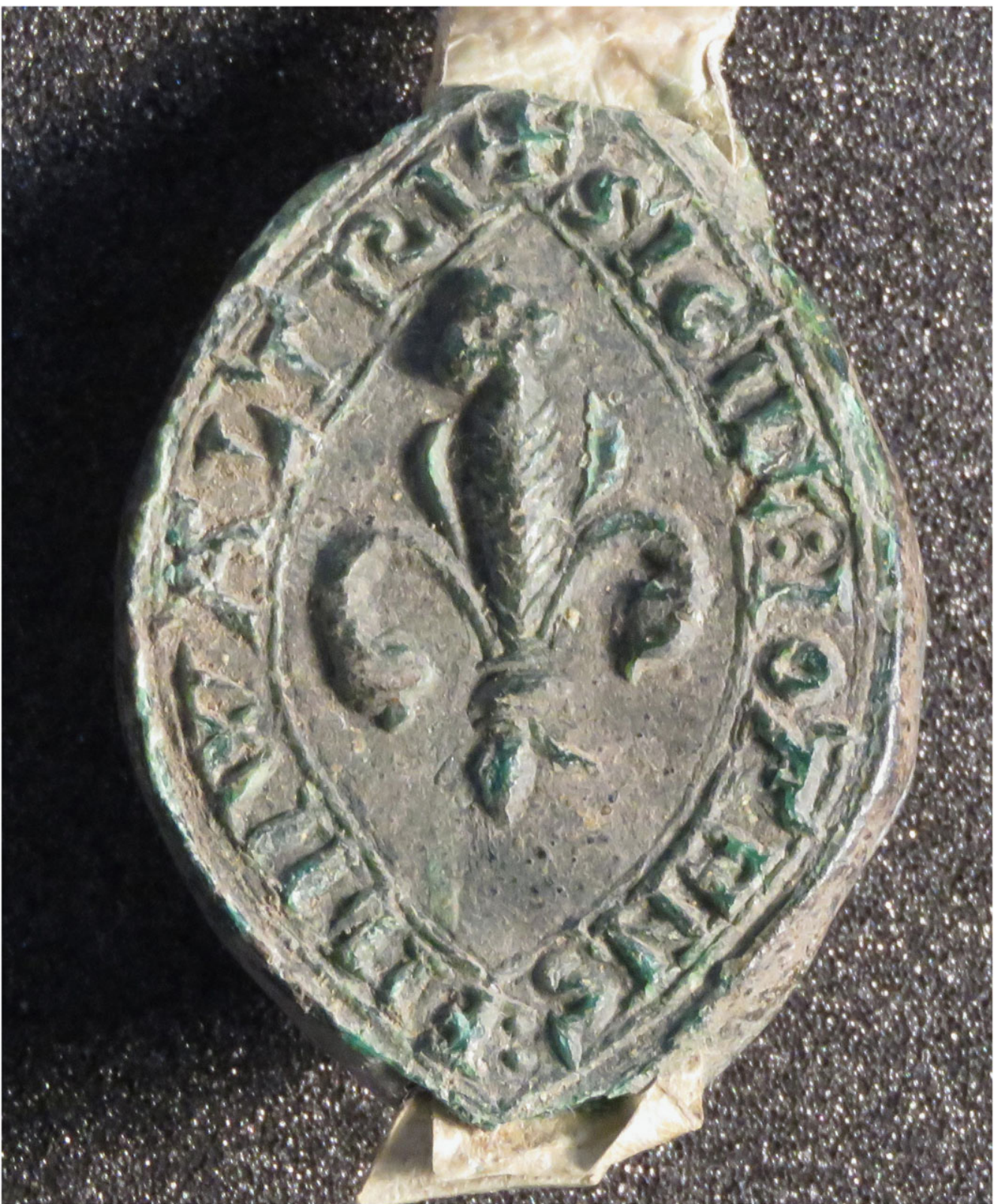

Fig 2c. Impression of the seal of John, son of Walter (HCA 832). Photograph: the authors.

and front legs of a stag at full gallop - a dynamic and striking image (fig 2e). ${ }^{65}$ Stags are found on a number of thirteenth-century seals across England and Wales, and the stag head full-face (caboshed) remained a popular sigillographic motif throughout the Middle Ages, but the form on Osbert's seal is unusual. This is the only instance, apart from the seal of Hugh, son of Ailmund, where we have additional information from the 


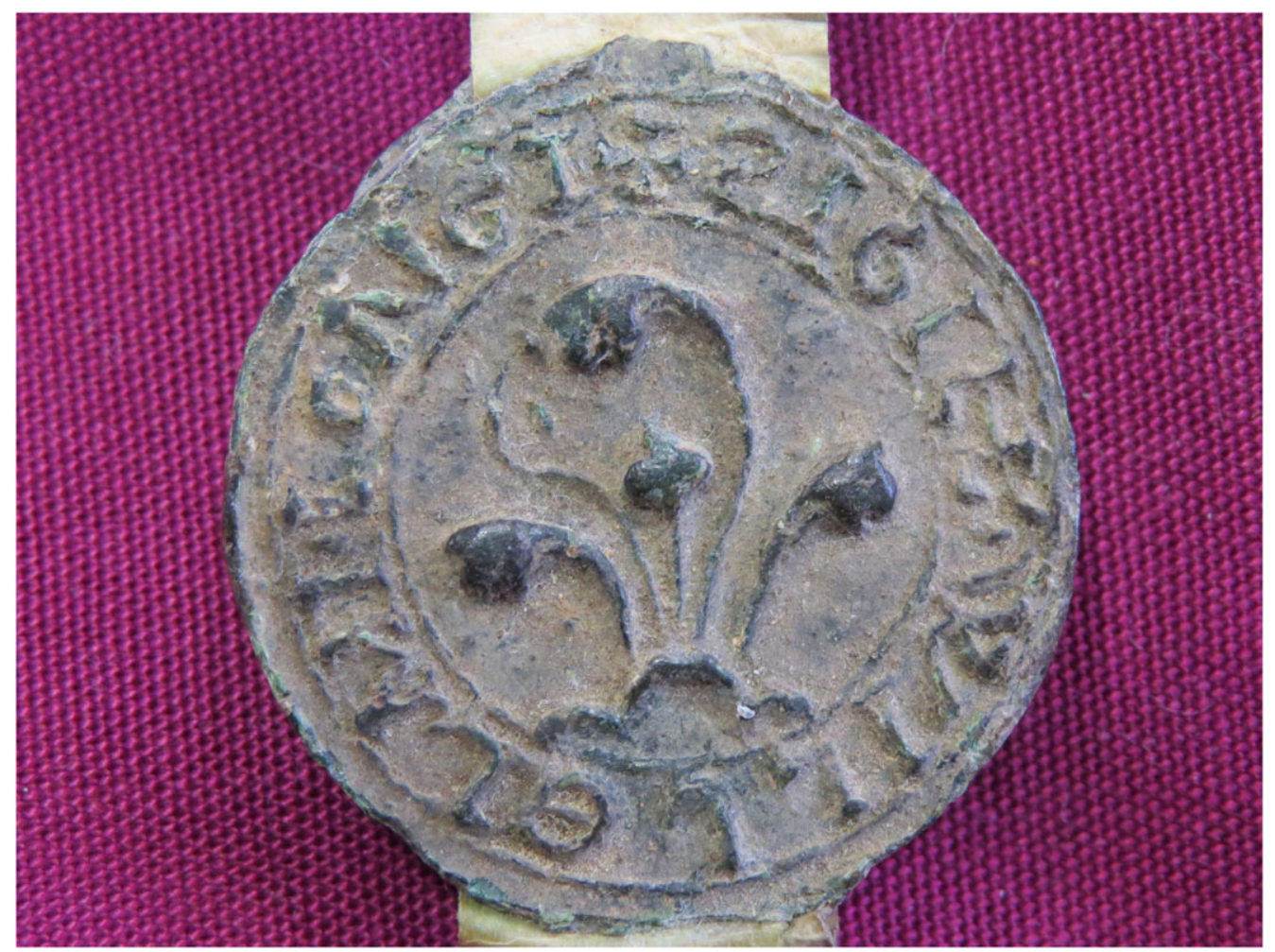

Fig 2d. Impression of the seal of William Long (HCA 915). Photograph: the authors.

impression about the form of the matrix, for part of the handle-loop at the top of the matrix was impressed into the wax. This also makes it somewhat surprising that this is one of the examples where the matrix was impressed off-centre to the wax cakes and tag, since the handle-loop would presumably have assisted the sealer correctly in orientating their matrix.

Without an investigation of the handprints on the wax, there would be nothing to indicate that the same person was involved in the physical act of impressing the matrix in the five items under investigation. The images and what we can tell of the matrices suggest men of a certain status with access to engravers producing high quality goods, but they do not link one sigillant to another. There is, then, no clear connection between the five sealed documents focused upon in this paper in terms of their construction or sealing. This in itself raises a number of challenging questions about how we investigate the documentary production, the development of clerical practice and, perhaps most importantly, how far we can rely on what contemporary records and modern assumptions reveal about the process of sealing. Nothing about the diplomatic or script of the grants suggests a single scribe or drafter was involved. Nor is there anything individual or particular about the sealing. There is no reason to assume that these documents were drafted or written at one time by one group of people, nor is there any clear link between the grantors or any coherence in the property they grant. The only evidence linking the sealing of the documents is the single palm print found on the reverse of each disk of wax.

The remaining most probable hypothesis, then, must be that the seals were attached by a single individual, who was connected with the only obvious link between the grants: their 


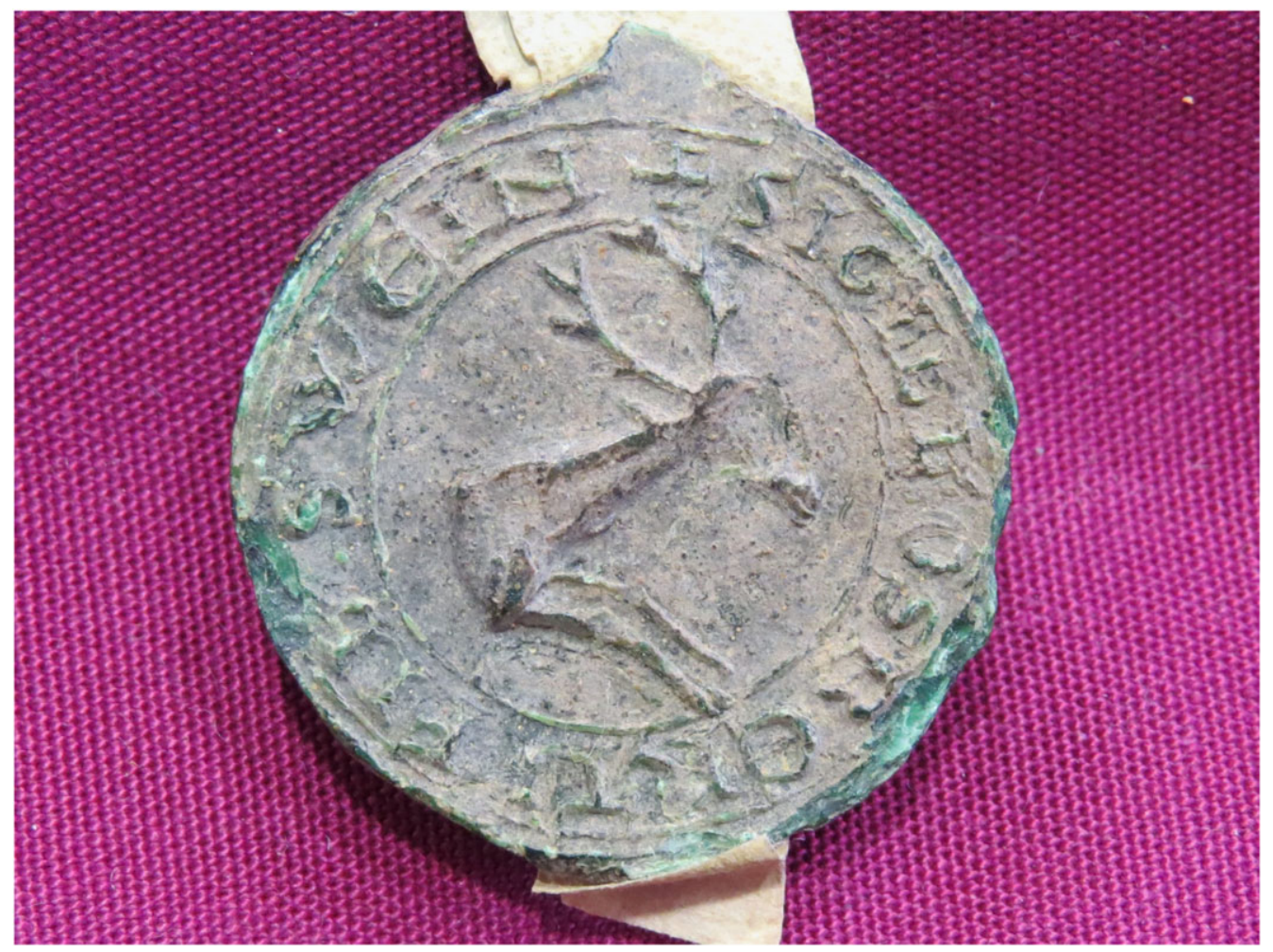

Fig 2e. Impression of the seal of Osbert, son of Suin (HCA 929). Photograph: the authors.

recipient, the Hospital of St Ethelbert. This individual was clearly confident with sealing: there are no obvious errors in his practice and slight mis-alignments of the matrix may speak to speed and the need to work efficiently rather than to any uncertainty about the process of impressing the matrix. However, in the broader context of other documents also issued for St Ethelbert's in this period, it is clear that, if the hospital was providing someone to take a part in the sealing practice, then that was not always the same person. Of the other documents examined by the project of the same quarter century for St Ethelbert's, nineteen provided exceptionally clear palm prints, and all nineteen of those prints are unique. ${ }^{66}$ Nor does this imply that in these cases the grantor was taking full control over the sealing process: there is more than one instance of two documents issued by the same individual having clear but different prints. ${ }^{67} \mathrm{We}$ can see, then, the traces of an institutional practice of sealing that involves someone other than the grantor whose matrix is being affixed but where that third individual is regularly changing. A broader context suggests that these developments in sealing reflect other processes in thirteenth-century document production, and that they tell us something about document production for St Ethelbert's Hospital in Hereford in particular.

66. HCA 808, 8I0, 825, 830, 846, 855, 859, 860, 878, 888, 890, 893, 903, 91 I, 916, 929, 932, 934, 938.

67. See documents with the seal of Walter of Lyde Godfrey, HCA 82I, to be compared with HCA 846,848 and 817. 
The number of prints found on this collection of seals suggests that it is unlikely St Ethelbert's were making use of their own chancery. By the thirteenth century, these sorts of documents, particularly issued in the names of moderate status secular individuals with no writing offices of their own, would have been recipient productions. In the I230s, we know the house was made up of a custos and three brothers, ${ }^{68}$ yet across twenty-five years we know at least seventeen people were involved in sealing of documents and even a brief glance at the hands of the documents to which the seals are attached suggests that they too include a considerable number of scribes. Even allowing for changes in personnel, this seems a large number for such a small house. There was, however, a larger institution very close to the hospital whose resources they could make use of. The hospital was adjacent to Hereford Cathedral, and its founder was a canon giving them an even closer link. Among the medieval charters it is clear that the property of the two institutions were sometimes confused, suggesting that the administration of the two organisations was not always kept separate, ${ }^{69}$ and the fact that the St Ethelbert deeds now form a part of the archive of the cathedral is also suggestive. It is very probable that the hospital made use of the nearby Dean and Chapter chancery when documents needed to be written, a chancery which, in the thirteenth century, would have been extensive. In this context, the prints upon the wax are likely to belong to the person responsible for preparing the wax and attaching it to the parchment tag for the impressing of the matrix. This would be the equivalent of the royal chancery's chafewax, although in the still developing chancery at a thirteenth-century cathedral it is likely that this was not a role attached to just one individual.

That suggests a close relationship between the cathedral and the hospital, which could have been thought of as a daughter institution. However, the handprint evidence also allows us to look at the process of sealing in conjunction with other developments in thirteenth-century document production. First, it ties developments in the Dean and Chapter's administration to those in contemporary episcopal chanceries. The first half of the thirteenth century provides the earliest evidence of English bishops' chanceries taking overall charge of formal episcopal sealing. That is, we begin to see a separation between the bishop in person and his legal authority as expressed by the affixing of his seal, with sealing undertaken by a professional as part of the administrative process of document production. ${ }^{70}$ This is all the more probable as in general the process of document creation, particularly for grants of land and rights, was, by the I230s, changing in England. Although in the I240s, the legal expert known as Bracton was still asserting that the process of granting land must be a physical one, taking place on the property itself, with the document only secondary, it is clear even in his assertion of this position that the document had become primary and that it, like the physical grant, was a tangible embodiment of the donor's agreement to this process, not just a record of it. ${ }^{7 \mathrm{I}} \mathrm{We}$ might think that this change should make little difference to sealing: as a seal became part of this demonstration of the will, surely the donor's part in attaching the seal would have become even more important. Yet, the effect that this change reflected in the document's production would also affect sealing. The document and the event itself were becoming distinct from each other, as Davit Broun has noted happens in the production of witnesses. Witnessing the production

68. HCA 994.

69. HCA 78I, 783, 980, 2,00I.

70. Cheney I950, 40-I; Hoskin 2012, 75-7.

71. See Haskins I938, 32 I-2; Thorne I985, 45-6. Michael Clanchy, however, notes that a preference for oral testimony over written and sealed evidence persisted in some quarters long into the thirteenth century: Clanchy 2013, 264-5, 297-300. 
of a document and witnessing the completion of the transaction through a particular ceremony become different elements in the I230s, with few witnesses appearing to have been present for the document's writing. ${ }^{72}$ Witnesses, like seals, were validatory parts of the document. As it was possible for these evidences of validation to become separated from the performative aspect of the grant, meaning that witnesses were no longer necessarily those who had been present on site for the ceremony of livery of seisin, so it was not necessary for that other validation, the sealing, to be closely connected to the same ceremony by being performed only by the individual sigillant. In fact, it may not have been necessary for all seals to be added to a document at the same time: in at least two thirteenth-century instances at Hereford, multiple seals on one document provided different prints. ${ }^{73}$ The most probable reason for this is that the seals were attached at different times, and the wax was provided for each individual seal, sealing was therefore prepared and held by different people.

An administrator, then, took a part in the sealing by holding the wax; separating in at least some instances the wax that received the imprint of the seal matrix from the physical presence of the sigillant. None of the St Ethelbert's sealing clauses, it should be noted, say that the grantor has affixed their seal, just that they have confirmed the grant through its impression. An argument from the use of standard phrases is not difficult to make, and may reflect the diplomatic preferences of the chancery, but affixi was also commonly found in charter corroborations and the choice of verb may be significant. It is by no means certain, however, that the grantors played no personal role in the impressing of their matrices. Almost certainly they would have been present - there is no reason to assume that they would have been long separated from their matrices: the only secular evidence we have of this sort of separation is for an official matrix, ${ }^{74}$ and those attached to the grants to St Ethelbert's are personal. There is also reason to think that they may still have been responsible for impressing the matrix. We have already noted that the document had become a physical embodiment of the donor's consent to a grant. Attaching an individual's seal without consent was enough to invalidate an agreement: in I293, at the Common Bench, the monks of the priory of St Swithin's, Winchester, were able to argue that the affixing of their seal to a bond was invalid because it had been done without their agreement. ${ }^{75}$ How would a donor's consent to sealing be recognised? The handing over of their matrix to an administrator may, just possibly, have been enough. They may also, though, have been expected to play a more active part, even if only in the presence of administrative officials. While one person held the wax, another could be responsible for impressing the matrix into it. Brand has noted an instance in the late thirteenth century when a reluctant female sigillant, Maude de Clovile, who claimed lack of expertise with sealing in her attempt to resist making land over to her father, was not forced to prepare the wax or to impress the matrix, but by removing the matrix herself she retained an involvement in the process, and her only partial involvement could have been connected both to her reluctance to consent to the sealed instrument and to her disavowal of the matrix itself (prepared for her by her father). ${ }^{76}$ At Hereford, if we look forward to the fourteenth

72. Broun 20II, 270-I.

73. HCA 855 has two seals with different prints. HCA 938 has three seals, two with matching prints and the third with a different one. Both are grants for St Ethelbert's Hospital from the second quarter of the thirteenth century.

74. Brand 20I5, II4-I5.

75. Ibid, II4, II5.

76. Ibid, II4. 
century, we can see practices that must demonstrate the sigillant's active involvement in sealing. The impression of knuckles, or even a thumb (for example, into the reverse of the wax), served no purpose of validation, but would have been a very visual way of signifying the seal owner's consent to the process, comparable to twelfth-century impressing of hair within the wax. ${ }^{77}$ Even where administrative process had taken over, a donor could be expected to be involved in the affixing of their own matrix.

\section{CONCLUSIONS}

The evidence of palm prints on the wax seals of thirteenth-century grants to St Ethelbert's Hospital, Hereford, demonstrates that administrative developments have, by this point, intervened between the owner of the matrix and the sealing of the document. It is clear that the grantor named in the documents was not always the individual responsible for attaching their seal to the document. There are occasions upon which both disparate seals share a print, and when two waxes with impressions of the same matrix have different prints; too many occasions to be explained by chance. This separation must be explained by the development of an administrative process, with a member of a chancery (in this case probably that of the Dean and Chapter at Hereford), who would have been needed to prepare the wax for sealing, taking a part in the impressing of the matrix by holding the wax seal. This intervention of an administrator between the matrix holder and the document which embodied their will in their grant suggests that the seal, like that other validatory element of the charter, the witness list, was becoming detached from the performance of livery of seisin in thirteenth-century England. This does not, however, necessarily mean that the donor now played no part in the sealing. While in the thirteenth century they left no mark on the wax, and so we cannot be certain whether the sigillant impressed their own matrix, seals of the fourteenth century related to cathedral documents include marks from knuckles and thumbs, which have no practical purpose and are reminiscent of earlier practices, such as the embedding of hair in the wax. ${ }^{78}$ While the matrix, then, was certainly still a part of the sigillant's identity, the sealed wax was both more and less than that.

\section{ACKNOWLEDGEMENTS}

The authors would like to thank Professor Phillip Schofield for his helpful comments on a draft of this article, and Professor Brigitte Bedos-Rezak, Professor Paul Harvey, Dr John McEwan, Dr Markus Späth, Professor Nicholas Vincent and Professor Tessa Webber for discussions about and advice on aspects of the underpinning research. The authors are also grateful to Mrs Rosalind Caird and the Reverend Canon Chris Pullen at Hereford Cathedral, and to Luke McGarr and Dr Karen Stow at Forensic Focus Ltd for their support for and assistance with the 2013 project, and the University of Lincoln for funding that project.

77. HCA II75, an agreement of the I320s between the Dean and Chapter of Hereford and one of its canons, has a definite thumb impressed into the back of the wax of the chapter's seal, for example.

78. These practices are currently being investigated by members of the Imprint project team. 


\title{
ABBREVIATIONS \& BIBLIOGRAPHY
}

\section{Abbreviations}

\author{
AHRC Arts and Humanities Research Council \\ HCA Hereford Cathedral Archives
}

\section{Bibliography}

Barrow, J 1999. 'The canons and citizens of Hereford, c II60-c I240', Midland Hist, 24, I-23

Barrow, J (ed) 2002. Fasti Ecclesiae Anglicanae 8: Hereford 1066-I300, Institute of Historical Research, London

Bedos-Rezak, B M 2006. 'Replica: images of identity and the identity of images', in J F Hamburger and A-M Bouché (eds), The Mind's Eye: art and theological argument in the Middle Ages, 46-64, Princeton University Press, Princeton

Bedos-Rezak, B M 2010. When Ego Was Imago: signs of identity in the Middle Ages, Brill, Leiden

Bedos-Rezak, B M 20I2. 'Image as patron: convention and invention in fourteenth-century France', in P Binski and E A New (eds), Patrons and Professionals in the Middle Ages, 216-36, Harlaxton Medieval Stud xxii, Shaun Tyas, Donington

Brand, P 2015. 'Seals and the law in the thirteenth century', in P R Schofield (ed), Seals and their Context in the Middle Ages, III-I9, Oxbow, Oxford

Broun, D 20II. 'The presence of witnesses and the writing of charters', in D Broun (ed), The Reality Behind Charter Diplomatic in Anglo-Norman Britain, University of Glasgow Press, Glasgow

Capes, W W (ed) I908. Charters and Records of Hereford Cathedral (84O-I42I), Wilson and Phillips, Hereford

Cheney, C R 1950. English Bishops' Chanceries IIOO-I25O, Manchester University Press, Manchester

Clanchy, M T 2013. From Memory to Written Record. England I066-I307, 3rd edn, WileyBlackwell, Oxford

Cole, S A 2002. Suspect Identities: a history of fingerprinting and criminal identification, Harvard University Press, Cambridge, Mass
Dryburgh, P and Hartland, B (eds) 2008. Calendar of the Fine Rolls of the Reign of Henry III: 9 to I8 Henry III, Boydell and Brewer, Woodbridge

Galbraith, V H and Tait, J (eds) I950. Herefordshire Domesday circa II60-II70: reproduced by collotype from facsimile photographs of Balliol College, manuscript 350, Pipe Roll Society Publications 63, NS 25, London

Golding, B I995. Gilbert of Sempringham and the Gilbertine Order c II30-c I300, Clarendon Press, Oxford

Harvey, P D A I99I. 'Personal seals in thirteenth-century England', in I Wood and G A Loud (eds), Church and Chronicle in the Middle Ages: essays presented to fohn Taylor, II7-27, Continuum, London and Rio Grande

Harvey, P D A and McGuinness, A 1996. $A$ Guide to British Medieval Seals, British Library, London

Haskins, G L 1938. 'Charter witness lists in the reign of King John', Speculum, I3 (3), 31925

Henig, M 2007. 'The re-use and copying of ancient intaglios set in medieval personal seals, mainly found in England: an aspect of the Renaissance of the I2th century', in N Adams, J Cherry and J Robinson (eds), Good Impressions: image and authority in medieval seals, 25-34, British Museum, London

Heslop, T A 1986. 'Seals as evidence for metalworking in the later twelfth century', in S Macready and F H Thompson (eds), Art and Patronage in the English Romanesque, 50-60, SAL Occasional Paper (New Ser) viii, London

Holden, B 2008. Lords of the Central Marches: English aristocracy and frontier society, I,087-I,265, Oxford University Press, Oxford 
Hoskin, P M 20I2. 'Authors of bureaucracy: developing and creating administrative systems in English episcopal chanceries in the second half of the thirteenth century', in P Binski and E A New (eds), Patrons and Professionals in the Middle Ages: proceedings of the 2010 Harlaxton symposium, 6I-78, Shaun Tyas, Donington

Jacquet, P 20I0. 'Radiologie et sigillographie', in M Gil (ed), Pourquoi les sceaux? La sigillographie nouvel enjeu de l'histoire de l'art, Publications de l'Institut de recherches historiques du Septentrion, Lille

Jenkinson, H 1968. A Guide to Seals in the Public Record Office, and edn, HMSO, London

McEwan, J A 20I5. 'The formation of a sealing society: London in the twelfth century', in Solway 2015, 319-20

McEwan, J A 2016a. Seals in Medieval London I050-I300, London Rec Soc Extra Ser I, London

McEwan, J A 20I6b. 'Seals in medieval Wales and its neighbouring counties: trends in motifs', in P R Schofield and E A New (eds), Seals and Society in Medieval Wales and its Border Region, 13-34, University of Wales Press, Cardiff

McGarr, L, Stow, K, Hoskin, P M and New, E A 20I6. 'A preliminary study of fingerprint ridge detail on medieval seals from Hereford Cathedral', Fingerprint Whorld, 4I, I60
New, E A 20I0. Seals and Sealing Practices, Brit Rec Soc Arch \& the User Io, British Records Association, London

New, E A 20I5a. 'Ecclesiastical seals', in P R Schofield and E A New (eds), Seals and Society: medieval Wales, the Welsh Marches and their English border counties, 6I-78, University of Wales Press, Cardiff

New, E A 2015b. 'The common seal and civic identity in medieval London', in Solway 20I5, 297-3I

New, E A 20I5c. '(Un)conventional images: a case-study of radial motifs on personal seals', in P R Schofield (ed), Seals and their Context in the Middle Ages, I5I-60, Oxbow, Oxford

Solway, S (ed) 2015. Medieval Coins and Seals: constructing identity, signifying power, Brepols, Turnhout

Thorne, S E 1985. 'Livery of seisin', in S E Thorne, Essays in English legal history, A \& C Black, London

Whitehead, D 1986. 'St Ethelbert's Hospital, Hereford: its architecture and setting', Trans Woolhope Naturalists Field Club, xlv, 4I4-25

Whitehead, D 2000. 'St Ethelbert's Hospital, Hereford', in G E Aylmer and J Tiller (eds), Hereford Cathedral: a history, A \& C Black, London

Woods, C I994. 'The nature and treatment of wax and shellac seals', f Soc Archivists, I5, 203-I4 